\title{
Physicochemical and Structural Properties of an Oxisol under the Addition of Straw and Lime
}

\author{
Márcio R. Nunes* \\ Dep. of Soil Sciences \\ Univ. of São Paulo \\ 11 Pádua Dias Ave. \\ Piracicaba, SP, 13418-900 \\ Brazil \\ and \\ Section of Crop and Soil Sciences \\ School of Integrative Plant Science \\ Cornell Univ. \\ Ithaca, NY, 14853

\section{Carlos M. P. Vaz} \\ Embrapa Agricultural Instrumentation \\ P.O. Box 741 \\ São Carlos, SP, 13560-970 \\ Brazil
}

\section{José E. Denardin}

Embrapa Wheat

BR 285 Road

Passo Fundo, RS, 99001-970

Brazil

\section{Harold M. van Es}

Section of Crop and Soil Sciences School of Integrative Plant Science Cornell Univ.

Ithaca, NY, 14853

\section{Paulo L. Libardi}

Dep. of Soil Sciences

Univ. of São Paulo

11 Pádua Dias Ave.

Piracicaba, SP, 13418-900

Brazil

and

Dep. of Biosystems Engineering

Univ. of São Paulo

11 Pádua Dias Ave.

Piracicaba, SP, 13418-900

Brazil

\section{Alvaro P. da Silva}

(in memoriam)

Dep. of Soil Sciences

Univ. of São Paulo

11 Pádua Dias Ave.

Piracicaba, SP, 13418-900

Brazil
Liming represents a common agricultural practice for abating soil acidity. Nevertheless, elevated amounts of agricultural lime in Oxisols, with or without cultural residue addition, could alter soil physicochemical properties and impact soil structure. In this context, the physical, chemical, and structural behaviors of an Oxisol under the addition of lime and straw were assessed. Lime doses $\left(0,3.9,7.8\right.$, and $\left.15.6 \mathrm{Mg} \mathrm{ha}^{-1}\right)$ were either applied on the surface or incorporated into the $0-$ to $5-\mathrm{cm}$ soil layer. Straw applications followed the same procedure with quantities of $0,4,12$, or $16 \mathrm{Mg} \mathrm{ha}^{-1}$. The effects on the soil profile were evaluated through physicochemical (specific surface area, $\zeta$ potential, and $\mathrm{pH}$ ), physical (density, penetration resistance, water dispersible clay, and total porosity), and micromorphological properties (surface area, volume, connectivity, size, and pore anisotropy) $1 \mathrm{yr}$ after soil incubation in polyvinyl chloride cylinders $30 \mathrm{~cm}$ long and $14.5 \mathrm{~cm}$ in diameter. Lime application on the surface or into the 0 - to $5-\mathrm{cm}$ layer increased soil $\mathrm{pH}$ to values above 7.0 and the electronegative potential of soil colloid surface, promoting clay dispersion. Water-dispersed clay migrated in the soil profile, causing pore obstruction, and higher soil density and penetration resistance. In addition, excessive lime decreased specific surface area, anisotropy degree and the connectivity of the soil pore system. Straw addition promoted a slight increase of colloids electronegative potential but did not alter soil physical properties.

Abbreviations: BD, bulk density; MDC, mechanically dispersible clay in water; NTU, nephelometric turbidity units; PR, penetration resistance; PVC, polyvinyl chloride; PZC, point of zero charge; RDC, readily dispersible clay in water; SMP, Shoemaker-McLean-Pratt method; ZP, $\zeta$ potential.

S oil structure is influenced by physical, chemical, and biological factors (Bronick and Lal, 2004; Abid and Lal, 2008), and its stability is a function of the interaction between particles and other soil components (Bolan et al., 1999; Baalousha, 2009). Among physicochemical properties acting on aggregation, colloid surface charge can promote either aggregate formation or dispersal (Stumm and Morgan, 1996; Fontes et al., 2001), especially in highly weathered Oxisols. In these, charge density depends on several factors, such as ionic strength, the $\mathrm{pH}$ of the solution, organic C, and soil mineralogy (Bolan et al., 1999; Sposito, 2008; Baalousha, 2009). Therefore, chemical and biological management could modify electrostatic properties and, as a result, Oxisols structural stability would also be altered.

\section{Core Ideas}

- Liming represents a common agricultural practice for abating soil acidity.

- High doses of lime on the Oxisol surface increases the electronegativity of the soil system.

- High electronegativity increases clay dispersion in the uppermost soil layer.

- Clay migration led to a series of physical alterations in soil subsurface layers.

- Overliming can lead to the degradation of highly weathered soil structures.

Soil Sci. Soc. Am. J. 81:1328-1339

doi:10.2136/sssaj2017.07.0218

Received 3 July 2017.

Accepted 25 Sep. 2017.

*Corresponding author (marcio_r_nunes@usp.br).

(c) Soil Science Society of America, 5585 Guilford Rd., Madison WI 53711 USA. All Rights reserved. 
Crop rotation and cultural residue management also affects soil structure. This is associated with interactions between organic $\mathrm{C}$ and other soil components. The effect could be either positive or negative, depending on deposited residue quantities and types as well as soil physicochemical conditions (Schutter and Dick, 2002; Cates et al., 2016). Soluble organic anion adsorption could diminish positive charges on oxide surfaces, inducing flocculation. Conversely, significant amounts of these anions could generate negative charges and promote soil dispersion (Ramos and McBride, 1996; Bolan et al., 1999). Anion adsorption by colloids may decrease the point of zero charge (PZC) of soil for low to medium $\mathrm{pH}$, whereas polyvalent metal adsorption can increase PZC (Coleman et al., 1989). This may cause a combined effect of cations and soluble organic anions, which may promote soil flocculation (Amézketa, 1999).

The addition of lime is a management practice that enhances agricultural crop yield in acid soils because of its potential to increase nutrient (notably P) availability, stimulate microbial activity, and reduce $\mathrm{Al}$ toxicity. Excessive lime, however, may lead to alterations in soil electrochemical properties. This would occur because of an increase in $\mathrm{pH}$ and a decrease in $\mathrm{Al}^{3+}$ activity, altering the solution electrolyte with possible impacts on soil structure (Uehara and Gillman, 1980). Soil pH controls both $\mathrm{H}^{+}$supply for oxide adsorption and functional groups dissociation from organic matter, influencing the density of Oxisol surface charges (Fontes et al., 2001). In this sense, negative charges would increase with $\mathrm{pH}$, which would reduce the attraction between kaolinite and oxides, resulting in repulsion between these particles (Ramos and McBride, 1996) and possible soil dispersion (Bolan et al., 1999; Fontes et al., 2001).

In agricultural Oxisols managed under no-tillage, the concentration of lime in the uppermost soil layer (Nunes et al., 2014) could aggravate the effect on colloidal surface electrostatic properties. This could lead to a series of alterations in soil physical properties, including a reduction in aggregate stability and an increase in clay dispersion (Roth and Pavan, 1991; Nunes et al., 2017). The water-dispersed clay may alter both pore size and continuity (Alaoui et al., 2011; Berisso et al., 2013). Moreover, water-dispersed clay may decrease soil permeability to water (Bolan et al., 1996) and to gases (Dörner and Horn, 2006), increasing the potential for clay concentration in floodwater (Roth and Pavan, 1991; Fontes et al., 1995), and lead to erosion-susceptible soil (Castro and Logan, 1991) and increases soil density in subsurface layers.

This research aimed to quantify the behavior of physicochemical and structural properties of an Oxisol under the addition of lime and crop residues. It is based on the following hypotheses: (i) the application of lime on the surface or into the uppermost soil layer promotes modifications in soil physicochemical properties and increases clay dispersion; (ii) water dispersible clay migrates in the soil profile, altering the pore system, density, and soil penetration resistance (PR); and (iii) crop residue addition decreases clay dispersion, improving soil properties.

\section{MATERIAL AND METHODS Experiment}

The Oxisol used in this study was classified as Rhodic Hapludox (USDA (2014) soil taxonomy) and Latossolo Vermelho Distrófico típico (Brazilian soil classification system; Santos et al., 2013). The Oxisol was sampled at 0 to $15 \mathrm{~cm}$ (A horizon) with a landscaping spade in an area that was never cultivated from Passo Fundo, state of Rio Grande do Sul, Brazil $\left(28^{\circ} 14^{\prime} 18^{\prime \prime} \mathrm{S}, 52^{\circ} 20^{\prime} 30^{\prime \prime} \mathrm{W}\right)$. The area was under native vegetation (native vegetation from the Mata Atlântica biome). The climate observed in the collecting region is humid subtropical (Cfa-Köppen classification), with annual precipitation of between 1300 and $1800 \mathrm{~mm}$, distributed uniformly during the year.

Five subsamples were separated with a 2-mm sieve, to determine potential soil acidity by the Shoemaker-McLean-Pratt (SMP) method (Shoemaker et al., 1961). The SMP method is one of most commonly used to estimate soil potential acidity in the soil region of this study. The SMP solution contains four chemical substances that act as weak bases to buffer the $\mathrm{pH}$ (triethanolamine, p-nitrophenol, potassium chromate, and calcium acetate), along with calcium chloride to control the ionic strength. It was determined that $7.8 \mathrm{Mg} \mathrm{ha}^{-1}$ of lime $(100 \%$ relative power of total neutralization) was required to efficiently raise the soil $\mathrm{pH}$ in water to 6.5 .

Polyvinyl chloride (PVC) cylinders $(30 \mathrm{~cm}$ height; $14.5 \mathrm{~cm}$ i.d.) were filled with the soil, and the sample's bulk density (BD) was established as $1200 \mathrm{~kg} \mathrm{~m}^{-3}$. Subsequently, lime dosages equivalent to $0,0.5,1$, and $2 \operatorname{SMP}\left(0,3.9,7.8\right.$, and $15.6 \mathrm{Mg} \mathrm{ha}^{-1}$ respectively) were added to the soil surface (Test I) or incorporated into the 0 - to 5 -cm soil layer (Test II). In a third trial, straw from a tropical grass, Brachiaria brizantha (A.Rich.) Stapf cv. Marandu, was incorporated in the 0 - to 5 -cm soil layer at doses of $0,4,12$, and $16 \mathrm{Mg} \mathrm{ha}^{-1}$. Prior to being added, the straw was ground into pieces approximately $5 \mathrm{~mm}$ long. The experimental design was a completely randomized block design, with four replicates, totaling 48 vessels.

Weekly irrigations of $30 \mathrm{~mm}$ (equal to $1 / 52$ of annual precipitation observed at the soil sampling site) were performed for 50 wk from 13 Apr. 2015 to 13 Mar. 2016 while the containers remained in a greenhouse, without humidity and temperature control. Average maximal and minimal temperatures in the greenhouse during the incubation period were 27.8 and $17.2^{\circ} \mathrm{C}$, respectively.

\section{Soil Characterization \\ Mineral Fraction}

Particle size analysis (Gee and Or, 2002) and soil particle density (Donagema et al., 2011) were quantified and the clay fraction mineralogy was qualitatively evaluated. To separate the clay fractions, the following steps were performed: soil organic matter removal with addition of hydrogen peroxide (30\% v/v; $1 \mathrm{~h}$ under room temperature and after $2 \mathrm{~h}$ under $\left.70^{\circ} \mathrm{C}\right)$, chemical dispersion with $10 \mathrm{~mL}$ of sodium hydroxide $\left(0.1 \mathrm{~mol} \mathrm{~L}^{-1}\right)$, mechanical dispersion with a Wagner agitator TE-160/24 (Tecnal, 
Piracicaba, Brazil) in a rotary movement of $360^{\circ}$ operating at 25 $\mathrm{rpm}$ for $16 \mathrm{~h}$, and sand fraction removal by sieving. The clay fraction was obtained by siphoning after the duration of silt fraction sedimentation, calculated according to Stokes' law. The soil material was characterized by X-ray diffraction (powder method) with a XRD 6000 (Shimadzu, Kyoto, Japan), with a Cu tube operated at $30 \mathrm{~mA}$ and $30 \mathrm{kV}$, equipped with $\theta$-compensating slit. The samples were scanned from 3 to $60(2 \theta)$ at a $0.5^{\circ}$ step size and a count time of 1 per step.

The clay fraction PZC was calculated from the $\zeta$ potential (ZP). Clay was suspended in $40 \mathrm{~mL}$ of $0.01 \mathrm{~mol} \mathrm{~L}^{-1} \mathrm{NaCl}$, from which $4 \mathrm{~mL}$ was pipetted into a 50 - $\mathrm{mL}$ beaker containing a $40-\mathrm{mL}$ solution of $0.01 \mathrm{~mol} \mathrm{~L}^{-1} \mathrm{NaCl}$ in preadjusted $\mathrm{pH}$ values of $2,3,5,6,8$, and 9 by means of $\mathrm{HCl}$ or $0.01 \mathrm{M}$ of $\mathrm{NaOH}$. Clay slurry was transferred to the electrophoretic cell of the Zetasizer Nano ZS equipment (Malvern, Malvern Instruments, UK) and $\mathrm{ZP}$ readings were measured. All analyses were performed in triplicate, with 10 to 20 readings per repetition.

\section{Soil BD by $\gamma$-ray attenuation}

At the 50th week of the experiments, irrigation was ceased and the soil samples were allowed to dry until a moisture content of $0.07 \mathrm{~m}^{3} \mathrm{~m}^{-3}$. Soil BD was determined in $2 \mathrm{~mm}$ intervals $(0-30$ cm sample height) via the $\gamma$-ray attenuation method with apparatus developed at Embrapa Instrumentation (Naime, 1994). Prior to scanning the soil columns with the $\gamma$-ray beam passing perpendicular to its longitudinal axis $\left(I_{a}\right.$, counts per s), three empty PVC cylinders were scanned at the same intervals to provide the blank attenuation counts $\left(I_{0}, \mathrm{cps}\right)$. Local atmospheric radiation $\left(I_{\text {atm }}\right)$ was determined from soil samples with a known $\mathrm{BD}$, and the mass attenuation coefficient $\left(\mu, \mathrm{cm}^{2} \mathrm{~g}^{-1}\right)$ of the studied soil was determined with soil samples with a known BD. Two complete scans were performed for each soil column and then averaged to provide a set of emerging radiation counts $\left(I_{\mathrm{a}}\right)$ from the soil column. The counting time for each measurement $(2 \mathrm{~mm}$ interval from 0 to $30 \mathrm{~cm}$ ) was $10 \mathrm{~s}$ in both blank attenuation counts and emerging radiation counts. The $\mathrm{BD}\left(\mathrm{g} \mathrm{cm}^{-3}\right)$ was calculated as follows:

$$
\mathrm{BD}=\frac{\left(\ln \frac{I_{0}-I_{\mathrm{atm}}}{I_{a}-I_{\mathrm{atm}}}\right)}{\mu x},
$$

where $x(\mathrm{~cm})$ is the internal diameter of the PVC cylinder.

\section{Resistance to Penetration}

The soil columns were stratified in layers of 0 to $2.5,5$ to $7.5,12.5$ to $15,17.5$ to 20 , and 25 to $27.5 \mathrm{~cm}$ as preserved structured soil in small cylinders $2.5 \mathrm{~cm}$ in height and $4 \mathrm{~cm}$ i.d. Soil PR was determine with an electronic bench penetrometer (CT3 Texture Analyzer, Brookfield, Middleboro, MA) equipped with a $25-\mathrm{kg}$ load cell, a data recording system, and a cone with a $30^{\circ}$ semiangle and a diameter of $3.81 \mathrm{~mm}$. Penetration velocity was $10 \mathrm{~mm} \mathrm{~min}^{-1}$, determined at $10 \mathrm{kPa}$ of soil water tension. All PR analyses were performed in triplicate.

\section{Water-Dispersible Clay}

Readily dispersible clay in water (RDC) and mechanically dispersible clay in water (MDC)(Dexter et al., 2011) were quantified for the 0- to 2.5-, 5- to 7.5-, 12.5- to 15-, 17.5- to 20-, and 25to $27.5-\mathrm{cm}$ layers. Five grams of ground soil was placed in $150-\mathrm{mL}$ flasks, to which $125 \mathrm{~mL}$ of deionized water was added. The flasks were manually flipped four times (gentle agitation) to quantify RDC and agitated at 100 excursions per minute in a horizontal shaker for $3 \mathrm{~h}$ (more rigorous agitation) to compute MDC. After stirring, the flasks were left undisturbed for $16 \mathrm{~h}$ for sedimentation of particles larger than clay (sand, silt, aggregates). Afterward, $30 \mathrm{~mL}$ of the suspension was transferred to a turbidimeter cell (Hach Turbidimeter 2100AN, Hach, Ames, IA), where its turbidity was measured in nephelometric turbidity units (NTU). The soil water content of the original soil samples was also determined to correct to the oven-dry soil mass (DSM) used to determine the dispersed clay. Turbidity was normalized by dividing NTU by the soil particle aggregate concentration $\left(C ; \mathrm{g} \mathrm{L}^{-1}\right)$ :

$$
\mathrm{RDC} \text { or } \mathrm{MDC}=\frac{\mathrm{NTU}}{C}=\frac{\mathrm{NTU}}{1000\left(\frac{\mathrm{DSM}}{125}\right)} \text {. }
$$

Turbidity corresponding to the percentage of total soil clay, determined via the pipette method (Gee and Or, 2002), was also quantified. After the required time for sand and silt sedimentation, a 30-mL aliquot was taken and transferred to the turbidimeter cell. The ratio between the total clay content (\%) and turbidity rates (in NTU gL ${ }^{-1}$ ) of the same soils represents a factor that when multiplied by other samples' $\mathrm{NTU} \mathrm{gL}^{-1}$ values, returns to the RDC and MDC (\%) soil quantities. Thus the values are presented as RDC and MDC percentage by total soil clay. All the RDC and MDC analyses were performed in triplicate.

\section{Computed X-ray Microtomography}

In layers at 0 to $2.5,12.5$ to 15 , and 25 to $27.5 \mathrm{~cm}$, samples with preserved structure were collected in PVC cylinders (2.5 $\mathrm{cm}$ height; $2.2 \mathrm{~cm}$ i.d.) and used for computed X-ray microtomography ( $\mu \mathrm{CT} \mathrm{X}$-ray) analysis. The scanning procedure was performed with a SkyScan 1172 X-ray microtomography system (Bruker, Kartuizersweg, Kontich,Belgium) following a threestep process. The X-ray source was fixed at $100 \mathrm{kV}$ and $100 \mu \mathrm{A}$, and the distances between the base, samples, and camera were adjusted to obtain a final resolution image of $12 \mu \mathrm{m}$ via the $2 \mathrm{~K}$ detector mode with the camera standard image mode enabled. Radiographic projection images were acquired in $0.3^{\circ}$ steps from 0 to $360^{\circ}$ (1200 projection images). The generated projections were reconstructed with NRecon software (Vaz et al., 2011).

The image processing analysis of the reconstructed microtomographic images was performed with CTan software (Bruker). Based on a set of bidimensional images (about 1000 "slices"), a region of interest was defined, excluding approximately $2 \mathrm{~mm}$ from the top, bottom, and edges of the scanned soil samples. Image binarization was conducted by following a method by Otsu (1979). The surface area, volume, and connectivity of soil pores 
were obtained from the set of binarized images. In addition, the fractal dimension was calculated via the Kolmogorov method and the degree of anisotropy was estimated according to Harrigan and Mann (1984). The degree of anisotropy can be considered an overall symmetry indicative of soil structure, in three dimensions, ranging from 0 (totally isotropic) to 1 (completely anisotropic). For each sample, seven "slices" of the binarized and cropped images were randomly selected to obtain the pore distribution in four size classes (30-75, 75-500, 500-1000, and 1000-2500 $\mu \mathrm{m})$.

\section{Specific Surface Area}

The superficial area was determined according to the Brunauer-Emmett-Teller $\mathrm{N}_{2}$ mathematical model (Brunauer et al., 1938) with the linear part of a $\mathrm{N}_{2}$ isotherm (between the pressure $p p_{0}{ }^{-1} 0.05$ and 0.35 ). This is possible because $\mathrm{N}_{2}$ is absorbed in contact with the samples at a temperature close to its condensation, thus covering the solid surfaces in a monolayer of calculated volume, recognizing the area occupied by the gas molecule $\left(0.162 \mathrm{~nm}^{2}\right)$ and the equilibrium pressure (Brunauer et al., 1938). According to the Brunauer-Emmett-Teller model, it is possible to calculate the specific surface area of solids by knowing the gas volume needed to cover a monolayer solid surface. A soil mass of approximately $5 \mathrm{~g}$ was placed in a glass burette and attached to the ASAP 2020 (Micromeritics, Norcross, GA) apparatus at a temperature of $-195.15^{\circ} \mathrm{C}$ (liquid $\mathrm{N}$ bath). Afterward, the samples were subjected to a vacuum treatment (degasification) to remove moisture and physically adsorbed gases. Pore distribution, including pores between 2.5 and $800 \mathrm{~nm}$, was calculated following the Barrett-Joyner-Halenda method (Barrett et al., 1951).

\section{Soil total porosity}

Soil total porosity (TP) was determined in layers with 0 to $2.5,12.5$ to 15 , and 25 to $27.5 \mathrm{~cm}$ by the ratio between soil $\mathrm{BD}$ and soil particles density (PD):

$$
\mathrm{TP}=\left(1-\frac{\mathrm{BD}}{\mathrm{PD}}\right) 100 \text {. }
$$

Pore size distribution was analyzed at both the nanometer and milimeter scale, applying the $\mathrm{N}_{2}$ gas adsorption technique $(0.0025-0.08 \mu \mathrm{m})$ and $\mu \mathrm{CT} \mathrm{X}$-ray technique (30$2500 \mu \mathrm{m})$. In accordance with Cameron and Buchan (2006), the pores obtained by gas adsorption, such as cryptopores $(0.00025-0.05 \mu \mathrm{m})$, were classified as well as those acquired by the $\mu \mathrm{CT}$ X-ray [i.e., mesopores $(30-75 \mu \mathrm{m})$ and macropores (three classes: $75-500 \mu \mathrm{m}, 500-1000$, and $1000-2500 \mu \mathrm{m}$ )]. The ultramicropores $(0-5 \mu \mathrm{m})$, and micropores $(4-30 \mu \mathrm{m})$ were not quantified because they were lower than the image spatial resolution of the $\mu \mathrm{CT} X$-ray images (considered here as 2.5 times the image spatial resolution or pixel size of $12 \mu \mathrm{m}$ ). Quantified cryptopores were divided according to methods used for their calculation (Barrett-Joyner-Halenda), with pores between 2.5 and $800 \mathrm{~nm}$, which were divided into four size classes: 2.4 to $20 \mathrm{~nm}, 20$ to 50,50 to $100 \mathrm{~nm}$, and 100 to $800 \mathrm{~nm}$.

\section{Zeta Potential}

The ZP was quantified to evaluate the surface charges of soil colloids [the ZP is the net electric charge that develops in the plane dividing the Stern layer and the diffuse layer at a given $\mathrm{pH}$ (Tan, 1998)]. Three grams of soil was mixed with $100 \mathrm{~mL}$ of distilled water and then allowed to settle for $5 \mathrm{~min}$ to enable larger particle decantation. An aliquot from the supernatant was used to quantify ZP with Zetasizer Nano ZS equipment (Malvern Instruments) with a voltage ranging from 50 to $150 \mathrm{mV}$. The apparatus microprocessor calculates the electrophoretic mobility of particles by converting them into $\mathrm{ZP}$, using the Smoluchowski equation, which denotes a direct relation between ZP and electrophoretic mobility (EM):

$$
\mathrm{ZP}=\frac{4 \pi V_{\mathrm{t}}}{D_{t}} \times \mathrm{EM},
$$

where $V_{\mathrm{t}}$ represents the liquid suspension viscosity, $D_{\mathrm{t}}$ is the dielectric permissivity, and EM is the electrophoretic mobility at the temperature.

\section{Statistical Analysis}

Treatment effects were assessed separately for each conducted assay and layer via ANOVA and means comparison with Tukey's test at $\alpha=0.05$ ( $\alpha=0.15$ for parameters of porous soil system morphology). Statistical analysis with confidence interval at $p=0.15$ (Payton et al., 2000) was done for water-dispersed clay, PR, and total porosity. The minimum significant difference at $\alpha=0.05$ was done for soil density. Finally, the specific surface area and soil pore size distribution were evaluated uniquely at each sample's SD.

\section{RESULTS \\ Oxisol Characterization}

The study soil is a sandy clay loam with $58 \%$ sand, $32 \%$ clay, $10 \%$ silt, and a particle density of $2670 \mathrm{~kg} \mathrm{~m}^{-3}$ (Table 1) and the Table 1. Some physical, chemical, and mineralogical attributes of the Oxisol studied, collected from a native system (horizon A, depth $\mathbf{0 - 1 5} \mathrm{cm}$ ).

\begin{tabular}{lcr} 
Soil attribute & Unit & Value \\
\hline Clay & $\mathrm{kg} \mathrm{kg}^{-1}$ & 0.32 \\
Silt & & 0.10 \\
Sand & & 0.58 \\
Particle density & $\mathrm{kg} \mathrm{m}^{-3}$ & 2.67 \\
Organic matter & $\mathrm{kg} \mathrm{kg}^{-1}$ & 0.26 \\
$\mathrm{pH}\left(\mathrm{CaCl}_{2}\right.$ ) & & 4.20 \\
Phosphorus & $\mathrm{mg} \mathrm{kg}^{-1}$ & 20.00 \\
Exchangeable P & $\mathrm{mmol}_{\mathrm{C}} \mathrm{kg}^{-1}$ & 1.50 \\
Exchangeable Ca & & 17.00 \\
Exchangeable Mg & & 10.00 \\
Exchangeable Al & & 12.00 \\
Potential acidity & & 96.00 \\
Sum of bases & & 28.00 \\
Cation exchange capacity & & 124.00 \\
Base saturation & $\%$ & 28.00 \\
Kaolinite in clay fraction & $\mathrm{kg} \mathrm{kg}^{-1}$ & 0.56 \\
pH at PZC (clay fraction) $\dagger$ & & 5.20 \\
\hline T PZC, point of zero charge & &
\end{tabular}




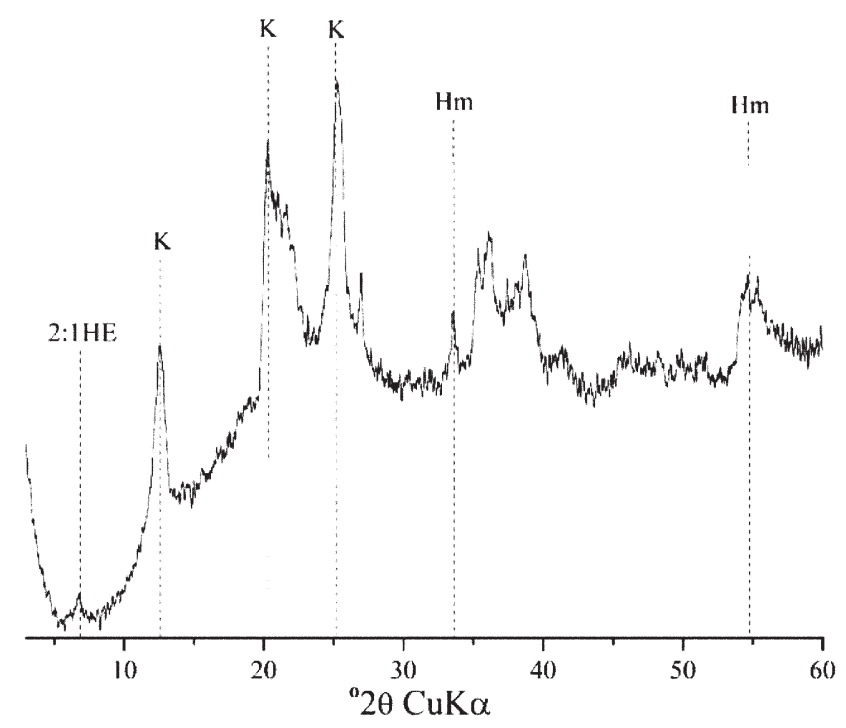

Fig. 1. X-ray diffraction (XRD) pattern of the clay fraction extracted from an Oxisol collected in the A horizon (depth: $\mathbf{0 - 1 5} \mathrm{cm}$ ) in a noncultivated area. HE, hydroxyl-interlayered; $\mathrm{K}$, kaolinite; $\mathrm{Hm}$, hematite.

mineralogy consisted mainly of kaolinite (56\%), hematite, and hydroxyl-interlayered 2:1 minerals (Fig. 1).

\section{$\mathrm{pH}$ and ZP}

The addition of agricultural lime on the surface, independently of its quantities, increased soil $\mathrm{pH}$ to values to above 7.3 , and increased soil colloid ZP in the 0 - to $2.5-\mathrm{cm}$ layer (Table 2). When the lime was incorporated into the 0 - to $5-\mathrm{cm}$ layer, a lime dose equivalent to $1 \mathrm{SMP}$ elevated both $\mathrm{pH}$ and $\mathrm{ZP}$ values in the topsoil layer $(0-2.5 \mathrm{~cm})$ as well. However, the $2 \mathrm{SMP}$ dosage augmented the $\mathrm{pH}$ in both the 0 - to $2.5-\mathrm{cm}$ and $5.0-$ to $7.5-\mathrm{cm}$ layer and the colloidal ZP in the 0 - to 2.5 -cm layer but, unlike surface application, even the 2 SMP did not increase $\mathrm{pH}$ values beyond 7.3.

Straw incorporation into the layer within 0 to $5 \mathrm{~cm}$ did not affect $\mathrm{pH}$ values but significantly raised the $\mathrm{ZP}$ of soil surface colloids down to $7.5 \mathrm{~cm}$ depth, depending on the application rate. This ZP increase on the soil colloids' surface was directly influenced by the water $\mathrm{pH}$ increase, principally in the soil that received surface lime addition and incorporation (Fig. 2A, B).

\section{Water-Dispersible Clay}

The addition of lime at the soil surface, independent of quantity, promoted an increase in water-dispersible clay concentrations in the 0 - to $2.5-\mathrm{cm}$ and $5.0-$ to $7.5-\mathrm{cm}$ soil layers (Fig. 3A, D). Lime incorporation $(0-5 \mathrm{~cm})$ increased the concentration of $\mathrm{RDC}$ in all layers in the 0 - and $15-\mathrm{cm}$ depth range, especially at 0 to $2.5 \mathrm{~cm}$ and 5 to $7.5 \mathrm{~cm}$ (Fig. 3B, E). On the other hand, incorporating straw $(0-5 \mathrm{~cm}$ layer $)$ did not alter the concentration of water-dispersible clay in the incubated Oxisol (Fig. 3C; 3F). The water-dispersible clay concentration in soil was directly influenced by the $\mathrm{pH}$ values of the soil water (Fig. 4).

\section{Soil BD, PR, and total porosity}

Both the addition of lime at the soil surface and incorporation of straw into the 0 - to $5-\mathrm{cm}$ layer did not significantly change $\mathrm{BD}$ values (Fig. 5A, C), PR (Fig. 6A, C) or total porosity (Fig. 6D, F). Lime incorporation into the 0 - to 5 -cm layer, however, reduced $\mathrm{BD}$ in the $0-$ to $3-\mathrm{cm}$ layer and increase it in the 12- to 20-cm soil stratum (Fig. 5B). The magnitude and depth of these effects were highest for the 2 SMP treatment (Fig. 5B) and resulted in concomitant decreases in total porosity and increased soil PR at the 12- to 20-cm depths (Fig. 6B, E).

Table 2. Soil $\mathrm{pH}$ in water and $\zeta$ potential of the disperse clay fraction extracted $1 \mathrm{yr}$ after incubation with different doses of $\mathrm{CaCO}_{3}$ and straw.

\begin{tabular}{|c|c|c|c|c|c|c|c|c|c|c|}
\hline \multirow{3}{*}{$\begin{array}{l}\text { Soil } \\
\text { depth, cm }\end{array}$} & \multicolumn{5}{|c|}{$\mathrm{pH}$ in water } & \multicolumn{5}{|c|}{$\zeta$ Potential $(-\mathrm{mV})$} \\
\hline & \multicolumn{4}{|c|}{ Doses of limestone applied on the surface } & \multirow[b]{2}{*}{ CV\% } & \multicolumn{4}{|c|}{ Doses of the limestone applied on the surface } & \multirow[b]{2}{*}{ CV\% } \\
\hline & O SMP & $0.5 \mathrm{SMP}$ & $1 \mathrm{SMP}$ & 2 SMP & & O SMP & 0.5 SMP & $1 \mathrm{SMP}$ & 2 SMP & \\
\hline $0-2.5$ & $5.97 \mathrm{bt}$ & $7.37 a$ & $7.57 a$ & $7.92 a$ & 6.27 & $16.61 b$ & $23.48 a$ & $21.99 a$ & $23.65 a$ & 5.86 \\
\hline $5.0-7.5$ & $6.15 \mathrm{a}$ & $6.31 \mathrm{a}$ & $6.33 \mathrm{a}$ & $6.31 \mathrm{a}$ & 6.21 & 19.20a & $20.58 \mathrm{a}$ & $20.03 \mathrm{a}$ & $21.66 \mathrm{a}$ & 12.89 \\
\hline $12.5-15.0$ & $5.94 a$ & $6.20 \mathrm{a}$ & $6.46 a$ & $6.07 \mathrm{a}$ & 6.62 & $19.79 \mathrm{a}$ & $21.08 \mathrm{a}$ & $19.52 \mathrm{a}$ & $20.87 a$ & 13.94 \\
\hline 17.5-20.0 & $5.83 a$ & $6.23 a$ & $6.13 a$ & $6.22 \mathrm{a}$ & 5.52 & $20.52 a$ & $20.62 a$ & $19.51 \mathrm{a}$ & $20.66 a$ & 18.04 \\
\hline \multirow[t]{3}{*}{$25.0-27.5$} & $5.81 \mathrm{a}$ & $5.85 a$ & $6.20 \mathrm{a}$ & $6.02 \mathrm{a}$ & 6.65 & $21.25 \mathrm{a}$ & $21.40 \mathrm{a}$ & $21.09 a$ & $20.41 a$ & 10.36 \\
\hline & \multicolumn{4}{|c|}{ Doses of limestone applied to the $0-5-\mathrm{cm}$ layer } & \multicolumn{6}{|c|}{ Doses of limestone applied to the $0-5-\mathrm{cm}$ layer } \\
\hline & o SMP & $0.5 \mathrm{SMP}$ & $1 \mathrm{SMP}$ & 2 SMP & CV\% & O SMP & $0.5 \mathrm{SMP}$ & $1 \mathrm{SMP}$ & 2 SMP & CV\% \\
\hline $0-2.5$ & $5.97 \mathrm{~b}$ & $6.62 \mathrm{ab}$ & $7.20 \mathrm{a}$ & $7.22 \mathrm{a}$ & 7.75 & $16.61 b$ & $19.58 \mathrm{ab}$ & $22.70 \mathrm{a}$ & $23.22 \mathrm{a}$ & 9.49 \\
\hline $5.0-7.5$ & $6.15 b$ & $6.55 \mathrm{ab}$ & $6.79 a b$ & $6.93 a$ & 5.56 & 19.20a & $20.36 a$ & $21.71 \mathrm{a}$ & $23.19 a$ & 11.44 \\
\hline $12.5-15.0$ & $5.94 a$ & $6.12 \mathrm{a}$ & $5.98 a$ & $6.26 a$ & 6.72 & 19.79a & $20.72 a$ & $20.89 a$ & $20.44 a$ & 9.41 \\
\hline $17.5-20.0$ & $5.83 a$ & $6.04 \mathrm{a}$ & $6.20 \mathrm{a}$ & $6.16 a$ & 6.72 & $20.52 a$ & $19.85 a$ & 19.89a & $19.52 \mathrm{a}$ & 15.54 \\
\hline \multirow[t]{3}{*}{$25.0-27.5$} & $5.81 \mathrm{a}$ & $6.11 \mathrm{a}$ & $5.99 a$ & $6.03 a$ & 6.35 & $21.25 \mathrm{a}$ & $20.58 a$ & $20.01 a$ & $21.11 \mathrm{a}$ & 15.66 \\
\hline & \multicolumn{4}{|c|}{ Doses of straw applied to the $0-5-\mathrm{cm}$ layer } & \multicolumn{6}{|c|}{ Doses of straw applied to the 0-5-cm layer } \\
\hline & $0 \mathrm{Mg} \mathrm{ha}^{-1}$ & $4 \mathrm{Mg} \mathrm{ha}^{-1}$ & $12 \mathrm{Mg} \mathrm{ha}^{-1}$ & $16 \mathrm{Mg} \mathrm{ha}^{-1}$ & CV\% & $0 \mathrm{Mg} \mathrm{ha}^{-1}$ & $4 \mathrm{Mg} \mathrm{ha}^{-1}$ & $12 \mathrm{Mg} \mathrm{ha}^{-1}$ & $16 \mathrm{Mg} \mathrm{ha}^{-1}$ & CV\% \\
\hline $0-2.5$ & $5.97 \mathrm{a}$ & $6.29 \mathrm{a}$ & $6.23 \mathrm{a}$ & $6.07 \mathrm{a}$ & 5.57 & $16.61 b$ & $22.74 \mathrm{a}$ & $24.01 \mathrm{a}$ & $25.21 \mathrm{a}$ & 6.14 \\
\hline $5.0-7.5$ & $6.10 \mathrm{a}$ & $6.22 \mathrm{a}$ & $6.12 \mathrm{a}$ & $6.19 \mathrm{a}$ & 5.82 & $19.20 b$ & $22.59 \mathrm{ab}$ & $22.87 \mathrm{ab}$ & $24.88 a$ & 11.04 \\
\hline $12.5-15.0$ & $5.94 a$ & $6.04 \mathrm{a}$ & $6.12 \mathrm{a}$ & $6.20 \mathrm{a}$ & 6.77 & 19.79a & $20.95 a$ & $19.75 a$ & $21.00 \mathrm{a}$ & 8.33 \\
\hline $17.5-20.0$ & $5.83 a$ & $5.97 a$ & $6.01 \mathrm{a}$ & $6.10 a$ & 7.51 & $20.52 a$ & $20.23 a$ & $20.68 a$ & $21.33 a$ & 14.60 \\
\hline $25.0-27.5$ & $5.81 \mathrm{a}$ & $5.99 a$ & $5.96 \mathrm{a}$ & $5.96 a$ & 6.51 & $21.25 a$ & $19.97 a$ & $20.42 a$ & $20.92 a$ & 11.97 \\
\hline
\end{tabular}

+ Numbers followed by the same letter within the same row do not differ, based on Tukey's test at $5 \%$ probability. 


\section{Computerized X-Ray Microtomography}

Pore morphological attributes measured by $\mu \mathrm{CT} \mathrm{X}$-ray image analysis were not significantly influenced $(p>0.15)$ by surface lime addition or straw incorporation into the 0 - to $5-\mathrm{cm}$ layer (Table 3). Conversely, application of lime into the 0 - to 5 -cm layer significantly modified $(p>0.15)$ soil pore morphology (Table 3), with higher applications reducing pore surface area at depths of 0 to $2.5 \mathrm{~cm}$ (Fig. $7 \mathrm{~A}$ ) and 15.0 to $17.5 \mathrm{~cm}$ (Fig. $7 \mathrm{~B})$, and also reducing porous anisotropy degree (Fig. 7C) and porous connectivity (Fig. $7 \mathrm{D}$ ) at a depth of 15.0 to $17.5 \mathrm{~cm}$.

\section{Pore-Size Distribution} and Specific Surface Area

Surface addition of lime did not affect pore size distribution in the soil stratum within the 15 - to 17.5 - and 25 - to $27.5-\mathrm{cm}$ depths (Fig. $8 B, C)$. Nonetheless, surface lime concentrations in the 0 to $2.5-\mathrm{cm}$ layer decreased the 1000 - to $500-\mu \mathrm{m}$ pore fraction and increased the 75- to 100 $\mu \mathrm{m}$ pore fraction (Fig. $8 \mathrm{~A}$ ). Furthermore, it reduced the volume of pores between 0 and $20 \mathrm{~nm}$ (Fig. 9A). Incorporation of lime into the 0 - to 5 - $\mathrm{cm}$ layer altered pore size and distribution in the 0 - to 2.5 - and 15 - to $17.5-\mathrm{cm}$ layers, with a decrease in larger diameter pores $(1000$ $2500 \mu \mathrm{m})$ and an increase in 75 - to $100-\mu \mathrm{m}$ pores (Fig. $8 \mathrm{D}$, E) but not those between 0 and $800 \mathrm{~nm}$ (Fig. 9B, C). There was no effect of agricultural lime in the 25- to $27.5-\mathrm{cm}$ soil layer (Fig. 8F, Fig. 9D), nor did straw addition change soil pore distribution (Fig. 8G-I).

The addition of agricultural lime, incorporated or not,
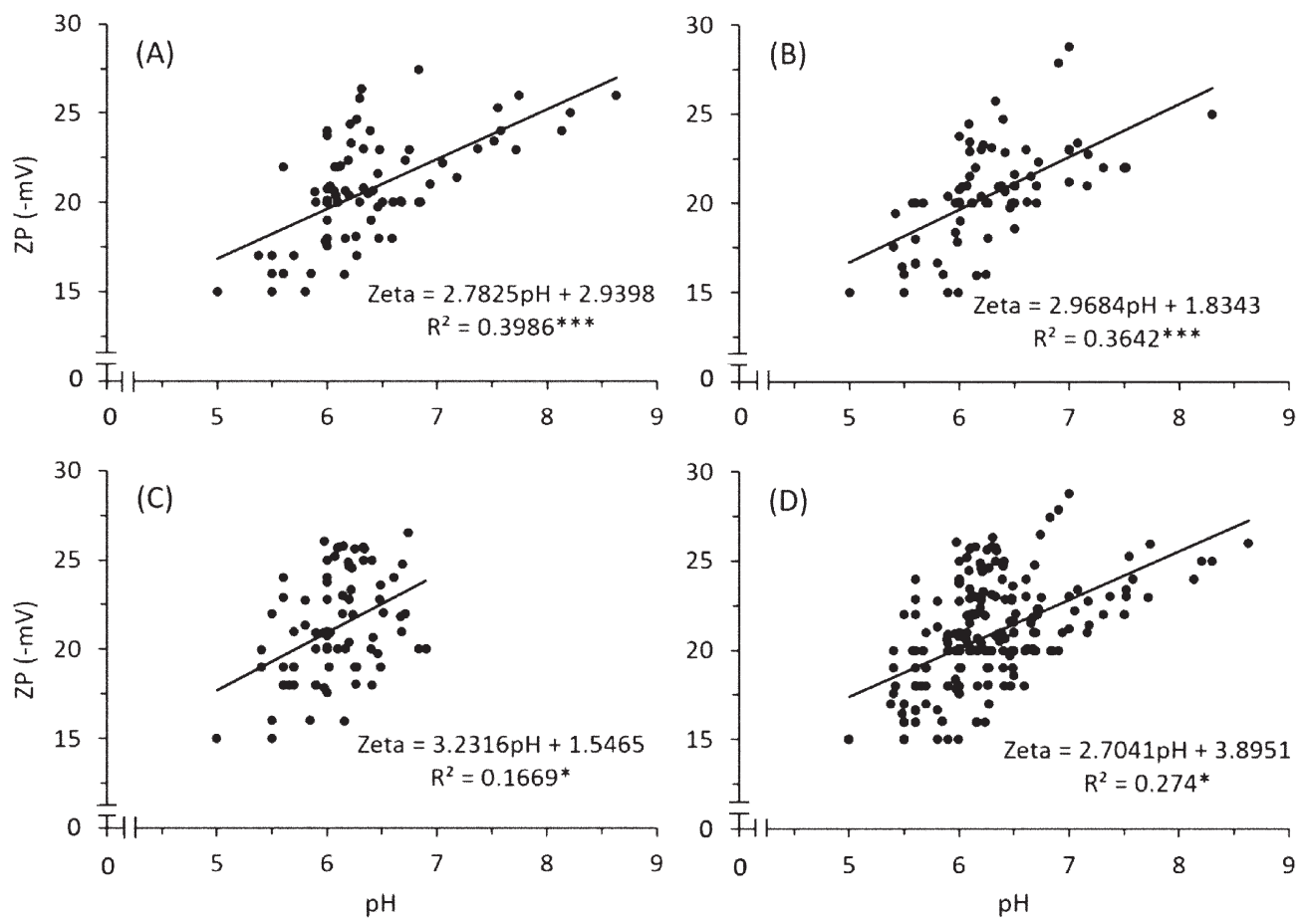

Fig. 2. Zeta potential (ZP) of the dispersed clay particles as a function of $\mathrm{pH}$ (in water), after $1 \mathrm{yr}$ of incubation with varying doses of $\mathrm{CaCO}_{3}$ applied on the soil column surface (A) or incorporated to a depth of 0 to $5 \mathrm{~cm}$ (B), and varying amounts of straw incorporated to a depth of 0 to $5 \mathrm{~cm}(C)$. Graph (D) includes all data points. ${ }^{* * *}$, significant at $\boldsymbol{p}=0.001 ;{ }^{*}$, significant at $\boldsymbol{p}=\mathbf{0 . 0 5}$.
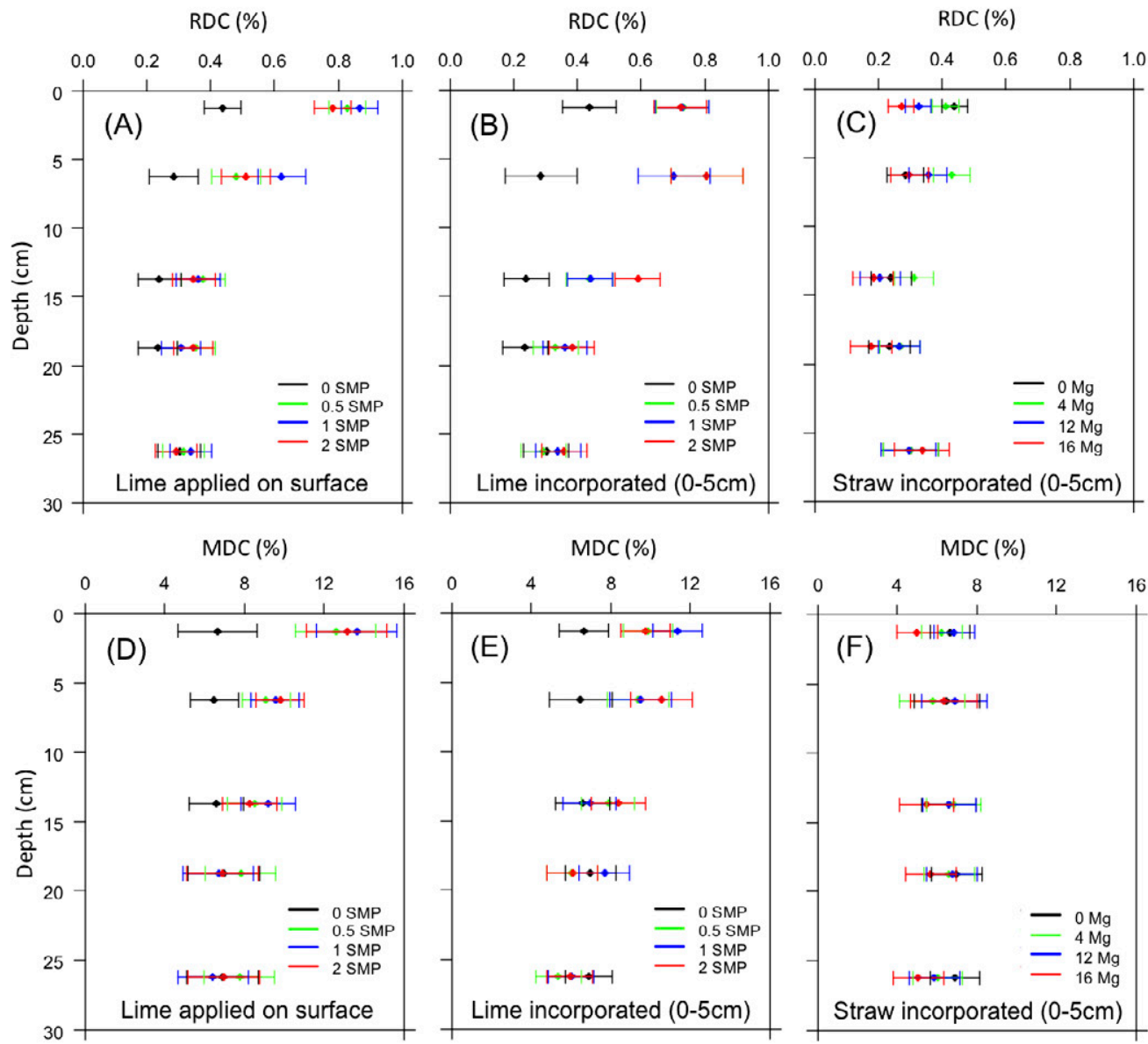

Fig. 3. Readily dispersible clay in water (RDC) and mechanical dispersible clay in water (MDC) of an Oxisol after $1 \mathrm{yr}$ of incubation with varying doses of $\mathrm{CaCO}_{3}$ applied to the soil column surface (A and D) or incorporated to a depth of 0 to $5 \mathrm{~cm}$ (B and $\mathrm{E}$ ) and varying amounts of straw incorporated to a depth 0 to $5 \mathrm{~cm}(\mathrm{C}$ and $\mathrm{F})$. Horizontal bars indicate the confidence intervals $(p=0.15)$ for the mean values. 

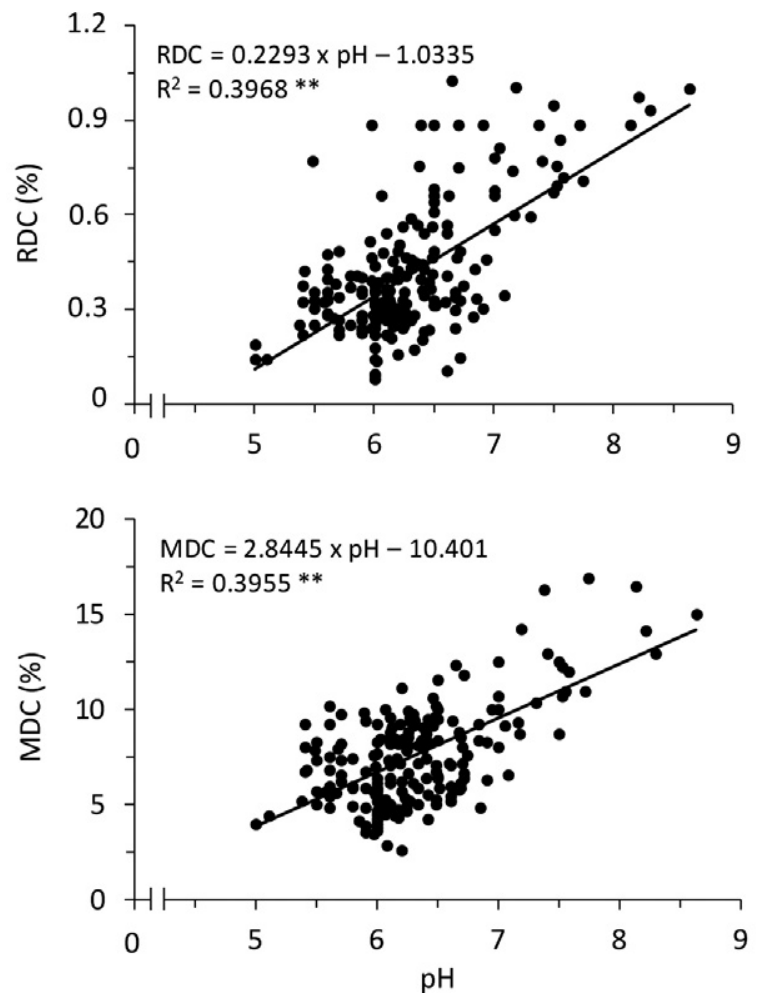

Fig. 4. Readily dispersible clay in water (RDC) and mechanical dispersible clay in water (MDC) as a function of the soil $\mathrm{pH}$ in water. Data displayed are from the three experiments $\left(\mathrm{CaCO}_{3}\right.$ applied at the surface, incorporated $\mathrm{CaCO}_{3}$, and incorporated straw). **, significant at $\boldsymbol{p}=\mathbf{0 . 0 1}$.

had no significant effect on soil surface area at any depth layer (Fig. 10A, B).

\section{DISCUSSION}

The surface application of agricultural lime at $0.5,1$, and 2 times the SMP index resulted in a $\mathrm{pH}$ increase in the 0 - to $2.5-\mathrm{cm}$ layer (7.3; Table 2) to values higher than those recommended for the majority of agricultural crops. Likewise, lime incorporation in the 0 - to 5 - $\mathrm{cm}$ stratum elevated $\mathrm{pH}$ to values of about 7.0 in the 0 - to $7.5-\mathrm{cm}$ layer (Table 2). This overliming in the surface layer was contrasted with inadequate $\mathrm{pH}$ benefits in the lower layers.

Higher $\mathrm{pH}$ levels were associated with an increase in $\mathrm{ZP}$ on soil colloid surfaces through colloid surface deprotonation (Table 2; Fig. 2), especially with the dominant kaolinite minerals (Tan, 1998; Aydin et al., 2004; Alkan et al., 2005). Even though kaolinite is formed by two basal layers that, in theory, are electrically neutral-one silicon tetrahedral and one aluminum octahedral-it is estimated that $10 \%$ of its total surface is covered by external surfaces and broken edges with reactive OH groups. Kaolinite PZC is relatively low (between 2.8 and 4.8; Tschapek et al., 1974), and soil $\mathrm{pH}$ increases (to about 7.5 in the present study) cause deprotonation of surface edges, increasing the liquid negative electric charge of soil in layers where $\mathrm{CaCO}_{3}$ has accumulated (Table 2). This electrostatic potential increase reduces attraction forces between kaolinite, and both $\mathrm{Fe}$ and $\mathrm{Al}$ oxides and enhance the repulsion forces between colloids (Ramos and McBride, 1996). As a result, colloidal suspension stability decreased (Tan, 1998).

The lime, depending on the amount, can generate dispersion in Oxisols, aside from the direct effect on $\mathrm{pH}$ (Fig. 4), resulting in $\mathrm{Al}^{3+}$ substitution by $\mathrm{Ca}^{2+}$ caused by $\mathrm{Al}^{3+}$ hydrolysis and precipitation (Fontes et al., 1995). In the soil solution, $\mathrm{Al}^{3+}$ forms a diffuse double layer that interacts synergistically with kaolinite, promoting clay flocculation (Roth, 1992). This phenomenon, in conjunction with organometallic compound formation, is the principal factor for aggregate stability in highly weathered soils (Barral et al., 1998; Six et al., 2000). Hence, the reduced Al cation activity further exacerbates soil colloids' electronegativity (Ramos and McBride, 1996) and stimulation of clay dispersion in these highly weathered soils (Fig. 3; Tama and El-Swaify, 1978).

This confirms that the lime concentration in the topsoil layer causes structural degradation in cultivated Oxisols resulting from clay dispersion (Fig. 3). Besides these results, several other studies, developed under field and laboratory conditions, have indicated

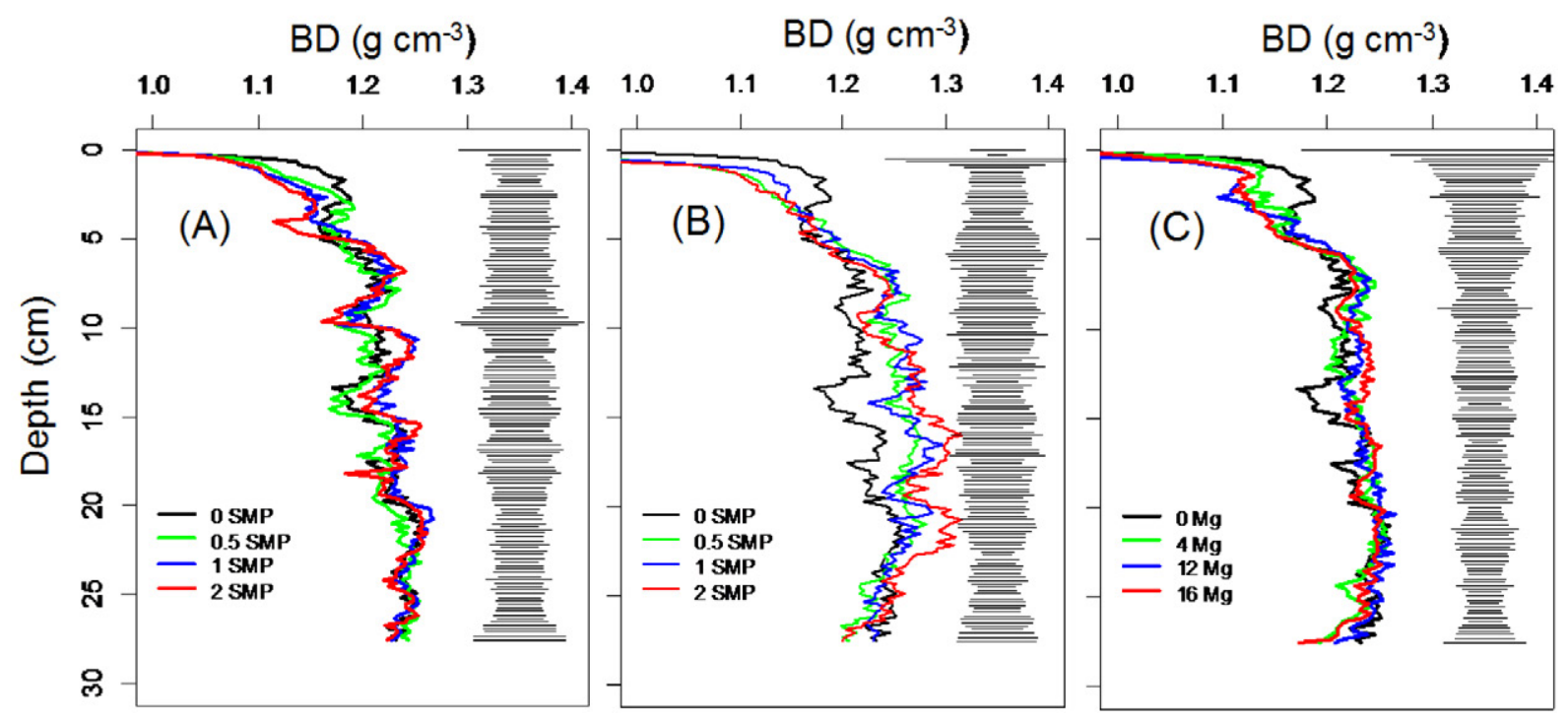

Fig. 5. Soil bulk density (BD) quantified by $\gamma$-ray attenuation at 2-mm intervals in the soil column profile. (A) $\mathrm{CaCO}_{3}$ applied to the soil surface, (B) $\mathrm{CaCO}_{3}$ applied to a depth of 0 to $5 \mathrm{~cm}$, and (C) straw applied to a depth of 0 to $5 \mathrm{~cm}$. Horizontal bars represent the least significant difference $(p=0.05)$. 

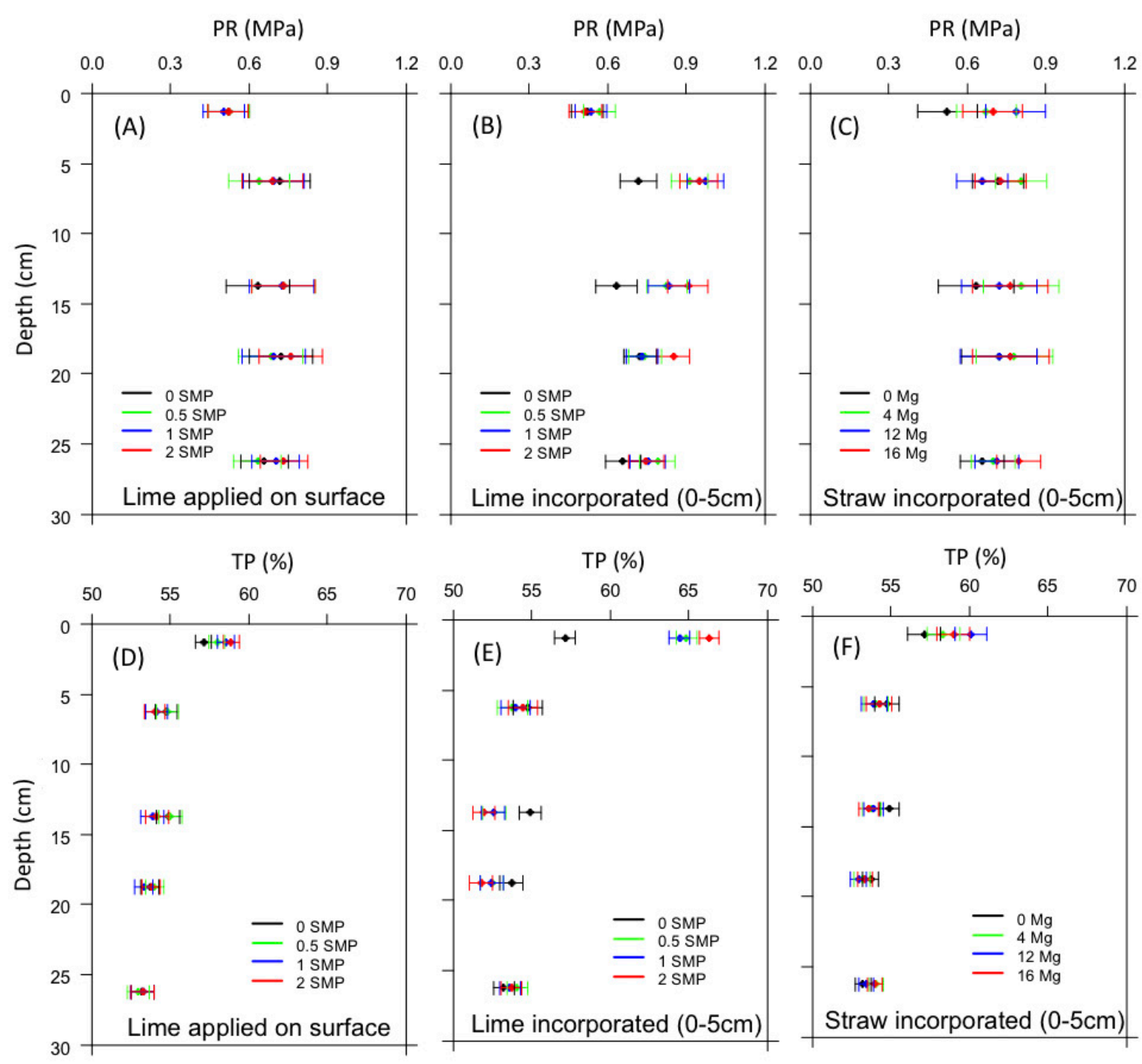

Fig. 6. Soil resistance to penetration (RP) and soil total porosity (TP) in an Oxisol after $1 \mathrm{yr}$ of incubation with varying doses of $\mathrm{CaCO}_{3}$ applied on the soil column surface ( $A$ and $D$ ) or incorporated to a depth of 0 to $5 \mathrm{~cm}$ (B and $E$ ), and varying amounts of straw incorporated to a depth of 0 to $5 \mathrm{~cm}(C$ and $\mathrm{F})$. Horizontals bars indicate the confidence intervals $(p=0.15)$ for the mean values.

that excessive liming could result in clay dispersion (or lower structure stability) in highly weathered soils such as Oxisols [for example: Ghani et al., 1955; Kamprath, 1971; Jucksch, 1987; Roth and Pavan, 1991; Gjorup, 1992; Fontes et al., 1995; Spera et al., 2008 (under laboratory conditions); Peele et al., 1939; Castro and Logan, 1991; Soprano, 2002; Nunes et al., 2017 (under field conditions)]. After being dispersed in the soil surface layer, water-suspended clay could create undesirable effects such as surface crust formation, soil fertility loss, and water pollution (Stern et al., 1991; Etana et al., 2009). In addition, dispersed clay can move into the soil profile with percolating water (Jacobsen et al., 1997; Etana et al., 2009), and generate increased soil density (12$20 \mathrm{~cm}$, Fig. 5B), pore obstruction, PR (Fig. 6B), and total porosity diminution (Fig. 6E) in lower soil layers. Clay migration has also reduced specific surface area (Fig. 7A and 7B), degree of anisotropy (Fig. 7C), and pore system continuity (Fig. 7D), and affected large di- ameter pores $(1000-2500 \mu \mathrm{m})$ in layers where clay dispersion or migration was observed (Fig. 8A, D, E).

Table 3. ANOVA of the soil pore morphological attributes of an Oxisol incubated with different doses of $\mathrm{CaCO}_{3}$ (on the surface or $0-5 \mathrm{~cm}$ depth) and straw incorporated to a depth of 0 to $5 \mathrm{~cm}$, measured by microCT image analysis. $t$

\begin{tabular}{|c|c|c|c|c|c|c|c|c|}
\hline \multirow{2}{*}{$\frac{\text { Soil depth }}{\mathrm{cm}}$} & \multicolumn{2}{|c|}{$\mathrm{TPV}_{\mu \mathrm{CT}}$} & \multicolumn{2}{|c|}{ PSA } & \multicolumn{2}{|c|}{ AD } & \multicolumn{2}{|c|}{ CP } \\
\hline & $P(>F)$ & CV\% & $P(>F)$ & CV\% & $P(>F)$ & CV\% & $P(>F)$ & CV\% \\
\hline \multicolumn{9}{|c|}{ Doses of limestone applied on the soil surface } \\
\hline $0-2.5$ & 0.966 & 14.52 & 0.665 & 10.40 & 0.880 & 12.72 & 0.570 & 37.95 \\
\hline $15.0-17.5$ & 0.926 & 10.58 & 0.548 & 7.48 & 0.864 & 5.11 & 0.240 & 13.55 \\
\hline $25.0-27.5$ & 0.869 & 13.32 & 0.797 & 10.47 & 0.989 & 9.73 & 0.995 & 21.45 \\
\hline \multicolumn{9}{|c|}{ Doses of limestone applied to the $0-5 \mathrm{~cm}$ soil layer } \\
\hline $0-2.5$ & 0.314 & 11.24 & 0.092 & 13.88 & 0.977 & 22.69 & 0.861 & 24.89 \\
\hline $15.0-17.5$ & 0.923 & 12.22 & 0.149 & 10.82 & 0.145 & 36.42 & 0.037 & 13.17 \\
\hline $25.0-27.5$ & 0.439 & 12.34 & 0.952 & 12.24 & 0.938 & 73.22 & 0.960 & 25.45 \\
\hline \multicolumn{9}{|c|}{ Doses of straw applied to the $0-5 \mathrm{~cm}$ soil layer } \\
\hline $0-2.5$ & 0.378 & 11.84 & 0.708 & 14.11 & 0.599 & 8.75 & 0.838 & 19.01 \\
\hline 15.0-17.5 & 0.582 & 10.30 & 0.157 & 18.20 & 0.991 & 24.93 & 0.537 & 22.40 \\
\hline $25.0-27.5$ & 0.756 & 9.12 & 0.880 & 11.61 & 0.976 & 12.50 & 0.967 & 26.35 \\
\hline
\end{tabular}

${ }_{\mathrm{TTPV}} \mathrm{TCT}$ total accessed porosity; PSA, pore surface area of the accessed porosity; A, degree of anisotropy in the porous system; PC, connectivity of the soil porous system. 

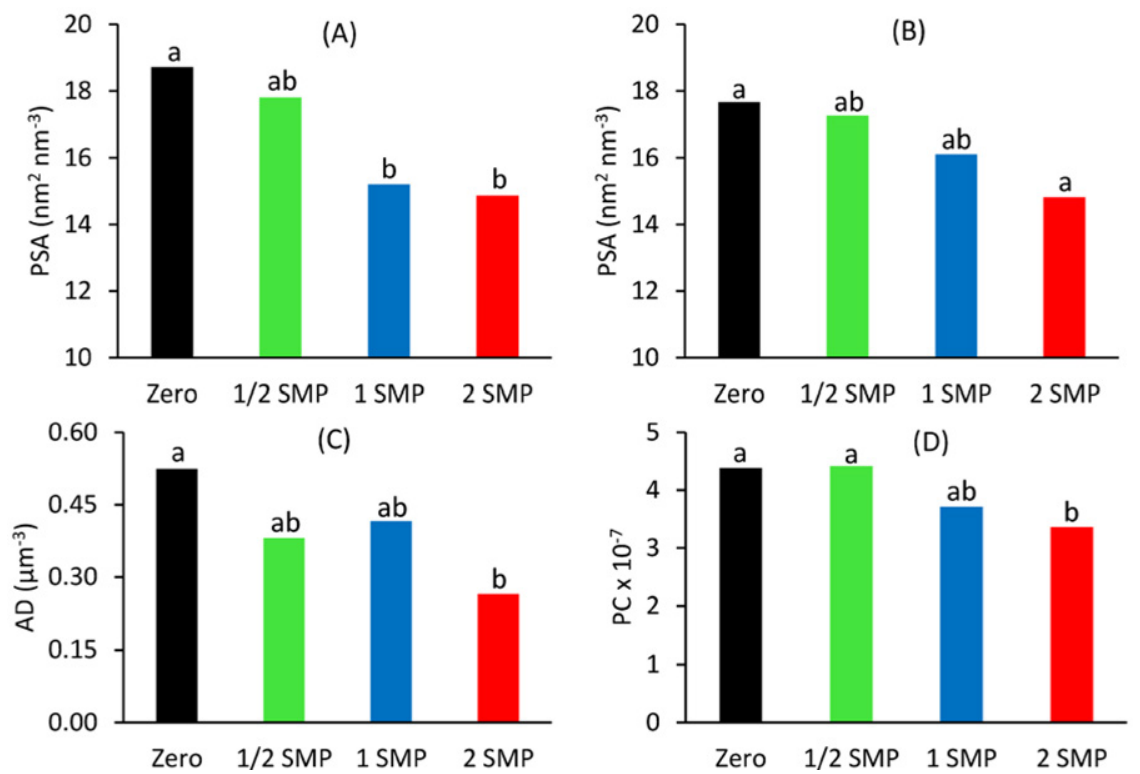

Fig. 7. Soil pore morphological attributes of an incubated Oxisol, obtained by computed microtomography $(\mu \mathrm{CT})$ image analysis $1 \mathrm{yr}$ after $\mathrm{CaCO}_{3}$ application to a depth of 0 to $5 \mathrm{~cm}$. PSA, pore surface area in soil cores collected at 0 to $2.5 \mathrm{~cm}(\mathrm{~A})$ and 15.0 to $17.5 \mathrm{~cm}$ in the soil columns (B); AD, degree of soil pore anisotropy at 15.0 to $17.5 \mathrm{~cm}(C)$; $P C$, pore connectivity at 15.0 to $17.5 \mathrm{~cm}(\mathrm{D})$.
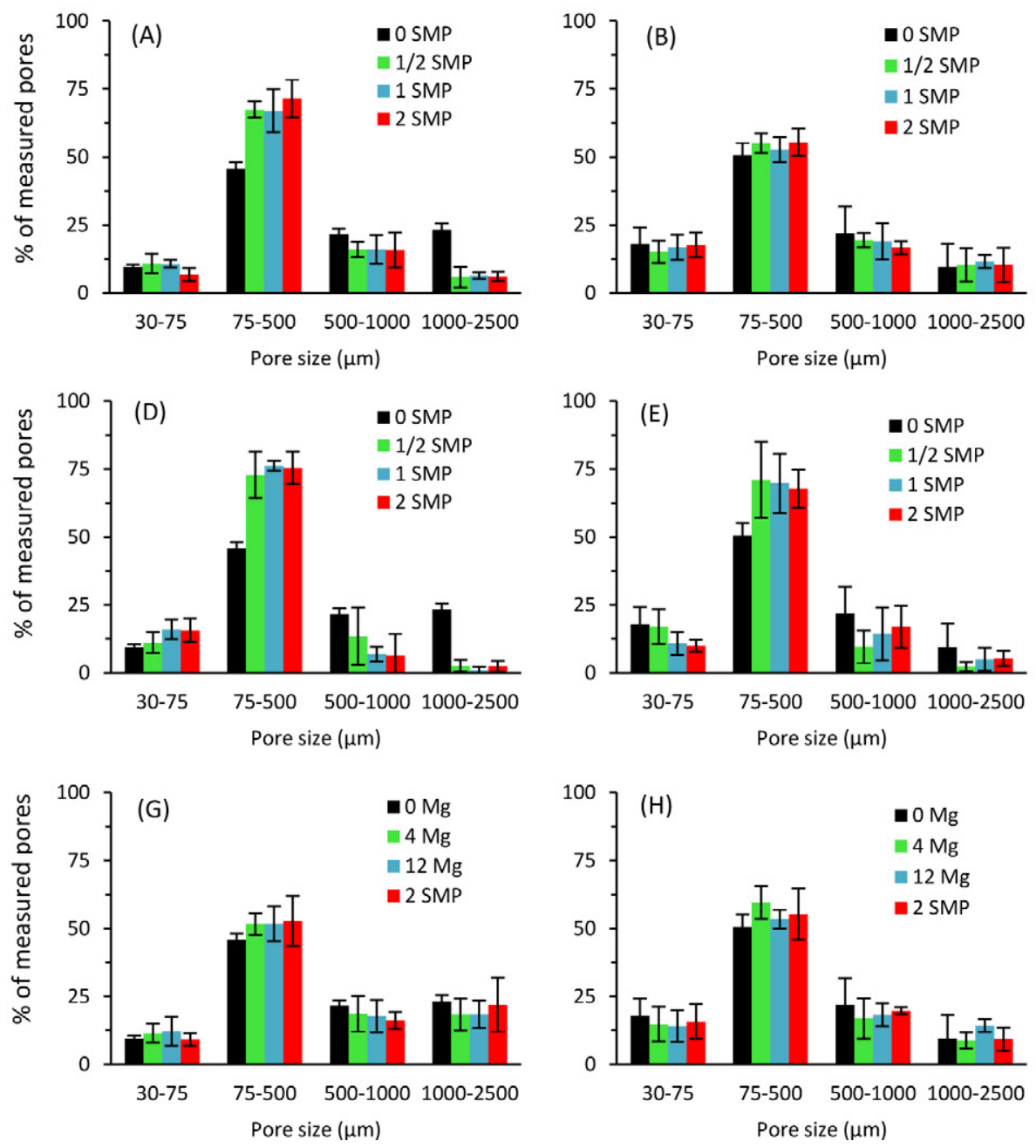

Liming that promotes clay dispersion and migration in the soil profile is therefore causing alterations in Oxisol's physical and functional properties under cultivation, also documented through decreases in water infiltration rates (Peele et al., 1939; Roth and Pavan, 1991) and soil permeability (Ghani et al., 1955; Kamprath, 1971). This is also a contributing factor in the formation of a dense subsurface layer observed in Oxisols after years of conventional farming or no-tillage (Jucksch, 1987; Roth, 1992; Fontes et al., 1995; Soprano, 2002). In this process, there is a dispersive environment in the soil surface layer, caused by overliming, and an aggregating environment in the subsurface layer, where the lime could not reach. After migrating from the surface layer to the subsurface layer, the clay can aggregate again, however, promoting soil densification (Fig. 5) and the degradation of soil functional properties as previously mentioned (Fig. 6, Fig.
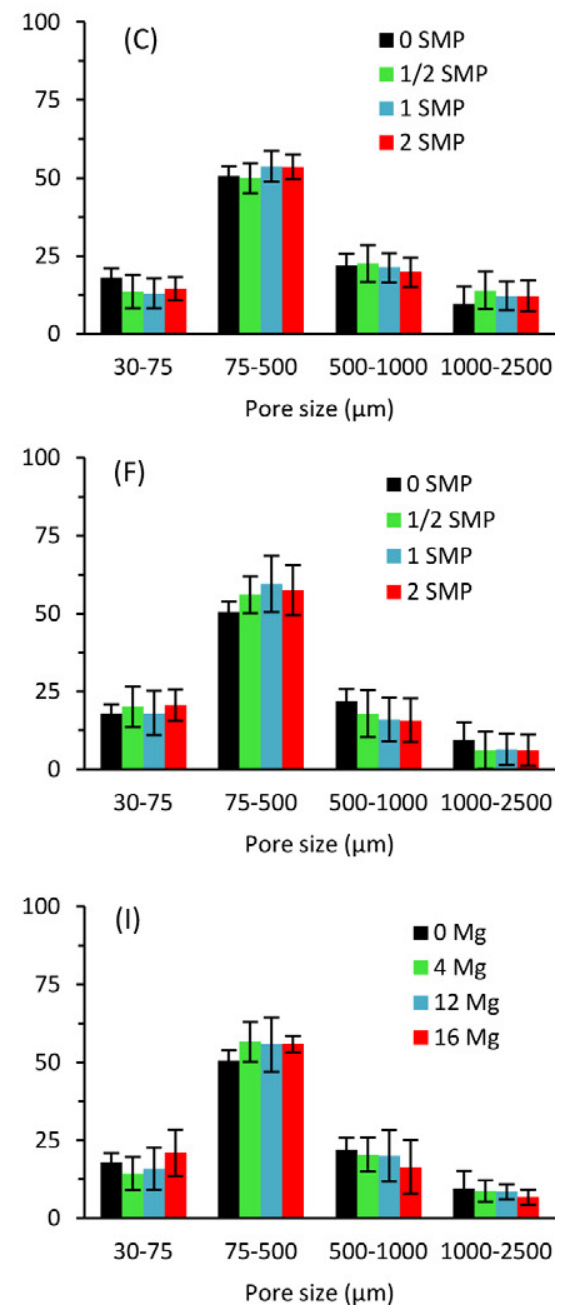

Fig. 8. Pore size distribution obtained by computed microtomography $(\mu \mathrm{CT})$ image analysis of an Oxisol incubated with $\mathrm{CaCO}_{3}$ applied on surface (A: samples collected at 0-2.5 cm, B: 15.0-17.5 cm, C: $25.0-27.5 \mathrm{~cm}$ ), incorporated in depth 0-5 cm soil (D: samples collected at 0-2.5 cm, E: 15.0-17.5 cm, F: 25.0-27.5 cm) and straw incorporated in depth $0-5 \mathrm{~cm}$ (G: samples collected at 0-2.5 cm, H: 15.0-17.5 cm, I: $25.0-27.5 \mathrm{~cm})$. Vertical bars indicate the standard deviation. 

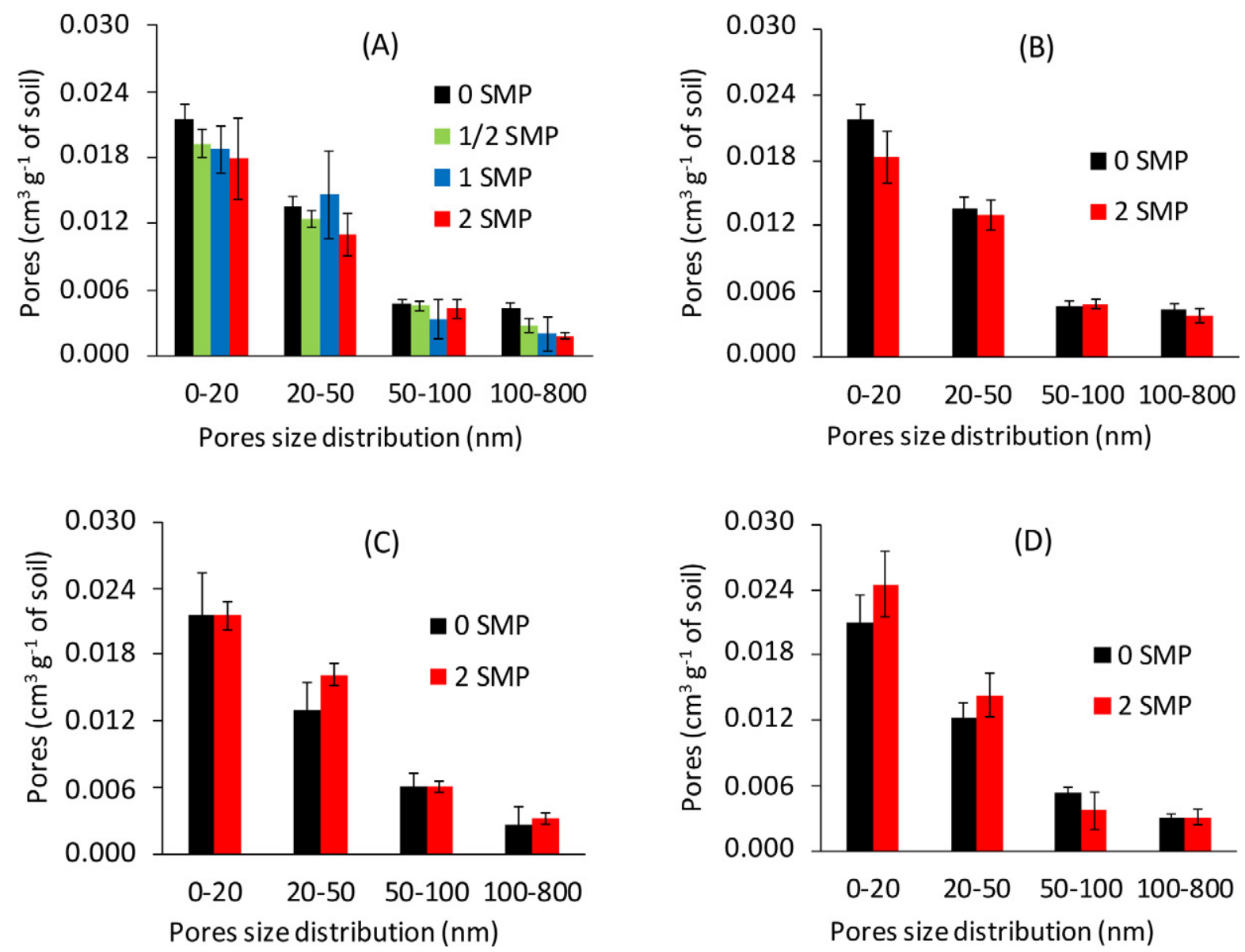

Fig. 9. Pores size distribution, obtained by Brunauer-Emmett-Teller analysis, of an Oxisol incubated with $\mathrm{CaCO}_{3}$ applied on the surface (A: samples collected at $0-2.5 \mathrm{~cm}$ ) and straw incorporated to a depth of 0 to $5 \mathrm{~cm}$ (B: samples collected at 0-2.5 cm; C: 15.0-17.5 cm; D: 25.0-27.5 $\mathrm{cm})$. Vertical bars indicate the SD.

7, and Fig. 8). These outcomes influence a soil's capacity to provide water and oxygen to plants (Ball et al., 1998) and are deleterious to environmental functioning.

Incorporating straw into the surface layer $(0-5 \mathrm{~cm})$ did not improve soil structure because of the short-term nature of the experiment, but augmented soil colloids' electronegativity (Table 2). This presumably resulted from reactive groups' dissociation of organic matter (Benites and Mendonça, 1998) and or-

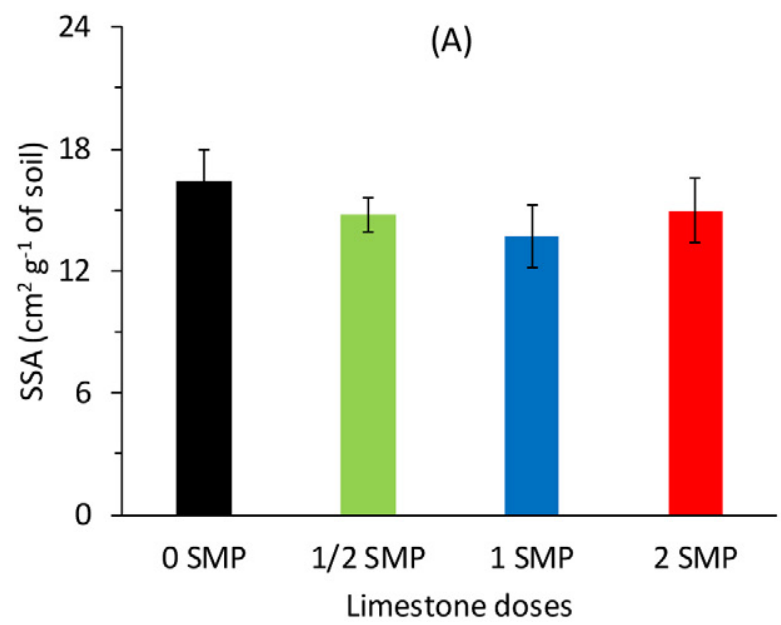

ganic anion adsorption to soil mineral colloids, which increases negative colloidal charges (Coleman et al., 1989). The effect of organic matter on Oxisols' electrochemical properties and soil dispersion have been observed in other studies (Benites and Mendonça, 1998; D’Acqui et al., 1999).

Fig. 10. Specific surface area (SSA), obtained by Brunauer-Emmett-Teller analysis, of an Oxisol incubated with CaCO $\mathrm{Cpplied}_{3}$ on the surface (A: samples collected at $0-2.5 \mathrm{~cm}$ ) and incorporated to a depth of 0 to $5 \mathrm{~cm}(B)$. Vertical bars indicate the SD. 


\section{CONCLUSIONS}

The results of this study show that the addition of agricultural lime at high doses on the surface of Oxisol, or lime incorporated into the topsoil layer $(0-5 \mathrm{~cm})$ significantly increased the $\mathrm{pH}$ and electronegativity of the soil system and resulted in clay dispersion in the topsoil layer. The resulting clay migration into the soil profile led to a series of structural alterations in subsurface layers, including increased density and PR, pore filling, obstruction and continuity, specific surface area, and degree of anisotropy. Soil can be enhanced by the implementation of the management practices of productive agricultural system, notably no-tillage, surface residue retention, and liming. However, overliming could also lead to the degradation of highly weathered soil structures. Therefore, liming (rate and application methods), mainly under no-till system, need to consider both the type and mineralogy of the soil, as well as possible soil structure degradation promoted by overliming in the uppermost soil layer.

\section{ACKNOWLEDGMENTS}

Thanks to the São Paulo Research Foundation, Brazil (process number 2015/12934-3) for the scholarships and funding. We express thanks also to the Brazilian Agricultural Research (Embrapa) for support.

\section{REFERENCES}

Abid, M., and R. Lal. 2008. Tillage and drainage impact on soil quality I. Aggregate stability, carbon and nitrogen pools. Soil Tillage Res. 100:8998. doi:10.1016/j.still.2008.04.012

Alaoui, A., J. Lipiec, and H.H. Gerke. 2011. A review of the changes in the soil pore system due to soil deformation: A hydrodynamic perspective. Soil Tillage Res. 115-116:1-15. doi:10.1016/j.still.2011.06.002

Alkan, M., Ö. Demirbas, and M. Doğan. 2005. Electrokinetic properties of kaolinite in mono and multivalent electrolyte solutions. Microporous Mesoporous Mater. 83:51-59. doi:10.1016/j.micromeso.2005.03.011

Amézketa, E. 1999. Soil aggregate stability: A review. J. Sustain. Agric. 14:83151. doi: $10.1300 / \mathrm{J} 064 \mathrm{v} 14 \mathrm{n} 02$

Aydin, M., T. Yano, and S. Kilic. 2004. Dependence of zeta potential and soil hydraulic conductivity on adsorbed cation and aqueous phase properties. Soil Sci. Soc. Am. J. 68:450-459. doi:10.2136/sssaj2004.4500

Baalousha, M. 2009. Aggregation and disaggregation of iron oxide nanoparticles: Influence of particle concentration, $\mathrm{pH}$ and natural organic matter. Sci. Total Environ. 407:2093-2101. doi:10.1016/j.scitotenv.2008.11.022

Ball, B.C., M.F. O'Sullivan, and R. Hunter. 1998. Gas diffusion, fluid flow and derived pore continuity indices in relation to vehicle traffic and tillage. Eur. J. Soil Sci. 39:327-339. 10.1111/j.1365-2389.1988.tb01219.x

Barral, M.T., M. Arias, and J. Guerif. 1998. Effects of iron and organic matter on the porosity and structural stability of soil aggregates. Soil Tillage Res. 46:261-272. doi:10.1016/S0167-1987(98)00092-0

Barrett, E., L. Joyner, and P. Halenda. 1951. The determination of pore volume and area distributions in porous substances. I. Computations from nitrogen isotherms. J. Am. Chem. Soc. 73:373-380. doi:10.1021/ja01145a126

Benites, V.M., and E.S. Mendonça. 1998. Electrochemical properties of an electropositive soil influenced by the addition of different organic matter sources. (In Portuguese with English abstract.) Rev. Bras. Ciênc. Solo 22:215-221. doi:10.1590/S0100-06831998000200006

Berisso, F.E., P. Schjønning, T. Keller, M. Lamandé, A. Simojoki, B.V. Iversen, et al. 2013. Gas transport and subsoil pore characteristics: Anisotropy and long-term effects of compaction. Geoderma 195/196:184-191. doi:10.1016/j.geoderma.2012.12.002

Bolan, N.S., J.K. Syers, and M.E. Sumner. 1996. Origin of the effect of $\mathrm{pH}$ on the saturated hydraulic conductivity of soils. Comm. Soil. Sci. Plant. Anal. 27:2265-2278. doi:10.1080/00103629609369702

Bronick, C.J., and R. Lal. 2004. Soil structure and management: A review. Geoderma 124:3-22. doi:10.1016/j.geoderma.2004.03.005

Bolan, N.S., R. Naidu, J.K. Syers, and R.W. Tillman. 1999. Surface charge and solute interactions in soils. Adv. Agron. 67:87-140. doi:10.1016/S00652113(08)60514-3

Brunauer, S., P.H. Emmett, and E. Teller. 1938. Adsorption of gases in multimolecular layers. J. Am. Chem. Soc. 60:309-319. doi:10.1021/ ja01269a023

Cameron, K.C., and G.D. Buchan. 2006. Porosity and pore-size distribution. In: R. Lal, editor, Encyclopedia of soil science. Taylor and Francis, New York. p. $1350-1353$.

Castro, C., and T.J. Logan. 1991. Liming effects on the stability and erodibility of some Brazilian Oxisols. Soil Sci. Soc. Am. J. 55:1407-1413. doi:10.2136/ sssaj1991.03615995005500050034x

Cates, A.M., M.D. Ruark, J.L. Hedtcke, and J.L. Posner. 2016. Long-term tillage, rotation and perennialization effects on particulate and aggregate soil organic matter. Soil Tillage Res. 155:371-380. doi:10.1016/j. still.2015.09.008

Coleman, D.C., J.M. Oades, and G. Uehara. 1989. Dynamics of soil organic matter in tropical ecosystems., University of Hawaii, Honolulu, HI.

D’Acqui, L.P., G.J. Churchman, L.J. Janik, G.G. Ristori, and D.A. Weissmann. 1999. Effect of organic matter removal by low-temperature ashing on dispersion of undisturbed aggregates from a tropical crusting soil. Geoderma 93:311-324. doi:10.1016/S0016-7061(99)00073-7

Dexter, A.R., G. Richard, E.E. Czyż, J. Davy, M. Hardy, and O. Duval. 2011. Clay dispersion from soil as a function of antecedent water potential. Soil Sci. Soc. Am. J. 75:444-455. doi:10.2136/sssaj2010.0088

Donagema, G.K., D.V.B. Campos, S.B. Calderano, W.G. Teixeira, and J.H.M. Viana. 2011. Manual de métodos de análise de solo. 2nd ed. Embrapa Solos, Rio de Janeiro.

Dörner, J., and R. Horn. 2006. Anisotropy of pore functions in structured Stagnic Luvisols in the Weichselien moraine region in N Germany. J. Plant Nutr. Soil Sci. 169:213-220. 10.1002/jpln.200521844

Etana, A., T. Rydberg, and J. Arvindson. 2009. Readily dispersible clay and particle transport in five Swedish soils under long-term shallow and mouldboard ploughing. Soil Tillage Res. 106:79-84. doi:10.1016/j. still.2009.09.016

Fontes, M.P.F., A.O. Camargo, and G. Sposito. 2001. Electrochemistry of colloidal particles and its relationship with the mineralogy of highly weathered soils. (In Portuguese with English abstract.) Sci. Agric. 58:627646. doi:10.1590/S0103-90162001000300029

Fontes, M.P.F., G.B. Gjorup, R.C. Alvarenga, and P.G.S. Nascif. 1995. Calcium salts and mechanical stress effects on water-dispersible clay of Oxisols. Soil Sci. Soc. Am. J. 59:224-227. doi:10.2136/ sssaj1995.03615995005900010034x

Gee, G.W., and D. Or. 2002. Particle-size analysis. In: J.H. Dane and G.C. Topp, editors, Methods of soil analysis. Soil Science Society of America, Madison, WI. p. 255-293.

Ghani, M.O., K.A. Hasan, and M.F.A. Khan. 1955. Effect of liming on aggregation, noncapillary pore space, and permeability of a lateric soil. Soil Sci. 80:469-478. doi:10.1097/00010694-195512000-00007

Gjorup, G.B. 1992. Influence of the dependent $\mathrm{pH}$ charge and of the exchangeable aluminum on the water dispersible clay. (In Portuguese with English abstract.) M.Sc. thesis. Federal Univ. of Viçosa, Viçosa, Brazil.

Harrigan, T.P., and R.W. Mann. 1984. Characterization of microstructural anisotropy in orthotropic materials using a second rank tensor. J. Mater. Sci. 19:761-767. doi:10.1007/BF00540446

Jacobsen, O.H., P. Moldrup, C. Larsena, L. Konnerup, and L.W. Petersen. 1997. Particle transport in macropores of undisturbed soil columns. J. Hydrol. 196:185-203. doi:10.1016/S0022-1694(96)03291-X

Jucksch, I. (1987) Limestone and clay dispersion in samples of an Oxisol. (In Portuguese with English abstract.) M.Sc. thesis. Federal Univ. of Viçosa, Viçosa, Brazil.

Kamprath, E.J. 1971. Potential detrimental effects from liming highly weathered soils to neutrality. Proc. Soil Crop Sci. Soc. Fla. 31:200-203.

Naime, J.M. 1994. Design and construction of a portable tomograph for studies on Soil Science and Plants. M.Sc. thesis. (In Portuguese with English abstract.) Univ. of São Paulo, São Carlos, Brazil.

Nunes, M.R., A.P. da Silva, J.E. Denardin, N.F.B. Giarola, C.M.P. Vaz, H.M. van Es, et al. 2017. Soil chemical management drives structural degradation of Oxisols under a no-till cropping system. Soil Res. doi:10.1071/SR17063

Nunes, M.R., J.E. Denardin, A. Faganello, E.A. Pauletto, and L.F.S. Pinto. 2014. Effect of seed drill with fixed shanks for deep action in soil under no-till. 
(In Portuguese with English abstract.) Rev. Bras. Ciênc. Solo 38:627-638. doi: 10.1590/S0100-06832014000200027

Otsu, N. 1979. A threshold selection method from gray-level histograms. IEEE Trans. Syst. Man Cybern. Syst. 11:23-27.

Payton, M.E., A.E. Miller, and W.R. Raun. 2000. Testing statistical hypotheses using standard error bars and confidence intervals. Commun. Soil Sci. Plant Anal. 31:547-551. doi:10.1080/00103620009370458

Peele, T.C., O.W. Beale, and E.E. Latham. 1939. Effect of lime and organic matter on the erodibility of Cecil clay. Soil Sci. Soc. Am. J. 3:289-295. doi:10.2136/sssaj1939.036159950003000C0058x

Ramos, A.C.H., and M.B. McBride. 1996. Goethite dispersibility in solutions of variable ionic strength and soluble organic matter content. Clays Clay Miner. 44:286-296. doi:10.1346/CCMN.1996.0440213

Roth, C.H. 1992. Soil sealing and crusting in tropical South America. In: M.E. Sumner and B.A. Stewart, editors, Advances in soil science. Soil crustingChemical and physical processes. Lewis Publishers, Boca Raton, FL. p. 267-300.

Roth, C.H., and M.A. Pavan. 1991. Effects of lime and gypsum on clay dispersion and infiltration in samples of a Brazilian Oxisol. Geoderma 48:351-361. doi:10.1016/0016-7061(91)90053-V

Santos, H.G., P.K.T. Jacomine, L.H. dos Anjos, V.A. Oliveira, J.B. Oliveira, M.R. Coelho, et al. 2013. Brazilian system of soil classification. 3rd edn. (In Portuguese.) Embrapa Solos, Rio de Janeiro.

Schutter, M.E., and R.P. Dick. 2002. Microbial community profiles and activities among aggregates of winter fallow and cover-cropped soil. Soil Sci. Soc. Am. J. 66:142-153. doi:10.2136/sssaj2002.1420

Shoemaker, H.E., E.O. McLean, and P.F. Pratt. 1961. Buffer methods for determining lime requirement of soils with appreciable amounts of extractable aluminum. Soil Sci. Soc. Am. Proc. 25:274-277. doi:10.2136/ sssaj1961.03615995002500040014x

Six, J., E.T. Elliott, and K. Paustian. 2000. Soil structure and soil organic matter:
II. A normalized stability index and the effect of mineralogy. Soil Sci. Soc. Am. J. 64:1042-1049. doi:10.2136/sssaj2000.6431042x

Soprano, E. 2002. Stability of aggregates and clay dispersion as function of liming. (In Portuguese with English abstract.) M.Sc. thesis. Federal Univ. of Rio Grande do Sul, Porto Alegre, Brazil.

Spera, S.T., J.E. Denardin, P.A.V. Escosteguy, H.P. Santos, and H.A. Figueroa. 2008. Dispersible clay in micro-aggregates of soil incubated with limestone. (In Portuguese with English abstract.) Rev. Bras. Ciênc. Solo 32:2613-2620. doi:10.1590/S0100-06832008000700002

Sposito, G. 2008. The chemistry of soils. Oxford Univ. Press: New York.

Stern, R., M. Ben-Hur, and I. Shainberg. 1991. Clay mineralogy effect on rain infiltration, seal formation and soil losses. Soil Sci. 152:455-462. doi:10.1097/00010694-199112000-00008

Stumm, W., and J.J. Morgan. 1996. Aquatic chemistry: Chemical equilibria and rates in natural waters. 3rd ed. Wiley, New York.

Tama, K., and S.A. El-Swaify. 1978. Charge, colloidal, and structural stability relationships in oxidic soils. In: W.W. Emerson, R.D. Bond, and A.R. Dexter, editors, Modification of soil structure. John Wiley and Sons, New York. p. 41-52.

Tan, K.H. 1998. Principles of soil chemistry, 3nd ed., M. Dekker: New York.

Tschapek, M., L. Tcheichvili, and C. Wasowski. 1974. The point of zero charge (PCZ) of kaolinite and $\mathrm{SiO}_{2}+\mathrm{Al}_{2} \mathrm{O}_{3}$ mixtures. Clay Miner. 10:219-229. doi:10.1180/claymin.1974.010.4.01

Uehara, G., and G.P. Gillman. 1980. Charge characteristics of soils with variable and permanent charge minerals: II. Experimental. Soil Sci. Soc. Am. J. 44:252-255. doi:10.2136/sssaj1980.03615995004400020009x

USDA. 2014. Soil taxonomy. USDA-NRCS: Washington, DC.

Vaz, C.M.P., I.C. Maria, P.O. Lasso, and M. Tuller. 2011. Evaluation of an advanced benchtop microcomputed tomography system for quantifying porosities and pore-size distributions of two Brazilian Oxisols. Soil Sci. Soc. Am. J. 75(3):832-841. doi:10.2136/sssaj2010.0245 